that we studied were born in either east Africa $(45 \%)$ or India $(45.5 \%)$. Only a few were born in Pakistan $(5 \%)$ or England (2\%). Less than one quarter of the Moslem mothers in our study were born in Pakistan, and $79 \%$ of Sikh mothers were born in India. The birth place of Hindu women were equally distributed between east Africa and India (Leicester Perinatal Mortality survey).

Our findings confirm the clinical impression that although Asians living in Britain are seen as one group, this population is far from homogenous, and the term Asian is imprecise for the purposes of clinical and epidemiological studies. Further regional studies are required to assess birth size among the Asian subgroups with an emphasis on socioeconomic and dietary factors.

We thank Miss E Mason and Professor M Clark for permission to use data from the Leicester Perinatal Mortality survey.

\section{References}

${ }^{1}$ Eveleth PB, Tanner JM. In: Worldwide variations in human growth. pp 228-412. Cambridge: Cambridge University Press, 1976:228-412.

2 Alvear J, Brooke OG. Fetal growth in different racial groups. Arch Dis Child 1978;53:27-32.

${ }^{3}$ Davies DP, Senior N, Cole G, Blass D, Simpson K. Size at birth of Asian and white Caucasian babies born in Leicester: implications for obstetric and paediatric practices. Early Hum Dev 1982;6:257-63.

${ }^{4}$ Clarson CL, Barker MJ, Marshall T, Wharton BA. Secular changes in birthweight of Asian babies born in Birmingham. Arch Dis Child 1982;57:867-71.

5 McFadyen IR, Campbell-Brown M, Abraham R, North WRS, Haines AP. Factors affecting birthweights in Hindus, Muslims and Europeans. Br J Obstet Gynaecol 1984;91:968-72.

${ }^{6}$ Lubchenco LO, Hansman C, Boyd E. Intrauterine growth in length and head circumference as estimated from live births at gestational ages from 26 to 42 weeks. Pediatrics 1961;37:403-8.

7 Wharton PA, Eaton PM, Wharton BA. Subethnic variation in the diets of Moslem, Sikh and Hindu pregnant women at Sorrento Maternity Hospital, Birmingham. Br $J$ Nutr 1984;52:469-76.

Correspondence to Dr M I Levene, Neonatal Unit, Department of Child Health, Leicester University Medical School, Leicester.

Received 24 April 1985

\title{
Acute hypothyroidism in a 3 year old
}

\author{
U MACFADYEN, B P O'MALLEY, AND P G F SWIFT \\ Departments of Child Health and Pharmacology, University of Leicester and the Department of Paediatrics, \\ Leicester Royal Infirmary
}

SUMMARY A 3 year old girl presented with a three week history of lethargy, constipation, and joint swelling. Investigation showed primary hypothyroidism associated with immunological changes including thyroglobulin antibodies. Reassessment several months after beginning thyroxine treatment confirmed persisting hypothyroidism. Primary hypothyroidism may present as a rapid onset disorder.

Primary hypothyroidism occurring in either children or adults is frequently autoimmune in origin arising from a chronic lymphocytic thyroiditis. ${ }^{12}$ It is also generally assumed that the development of symptomatic thyroid deficiency is a protracted process spanning months or even years ${ }^{3}$ which, in children, considerably affects growth and maturation. The acute development of primary hypothyroidism in a young child has not been described previously.

\section{Case report}

A girl aged 3 years 9 months born in England of non-consanguinous Asian parents presented with a three week history of lethargy and constipation. During this short period she had developed swelling of her hands and ankles and was reluctant to walk. She became increasingly tired, falling asleep at play school, and she refused her food. Bowel movements had become infrequent despite the use of laxatives and occasionally there were streaks of blood in her stool. In the two weeks before presentation her skin had become very dry. Bruising had developed over her knees, in the absence of any history of trauma. Perinatal, developmental, and previous medical histories were unremarkable. She was fully immunised. There was no family history of endocrine disorders.

On examination her height of $100 \mathrm{~cm}$ and weight of $11 \mathrm{~kg}$ were between the 75th and 95th centiles. She looked unwell with a pale puffy face. A moderate non-tender goitre was visible and palpable with no appreciable adenopathy. The skin was very dry and scaly particularly over the trunk and extensor aspects of her arms. There were several bruises over her knees. The proximal interphalangeal joints of the hands were swollen and there 
was non-oedematous, soft tissue swelling around the ankle joints associated with limitation of movement and pain. Her abdomen was distended, and the descending colon was loaded with faeces. Rectal examination confirmed the constipation. Other systems were normal.

Investigations showed a normal full blood count but red cell morphology showed anisocytosis and burr cells. Urea and electrolytes, liver function tests, and calcium phosphate values were normal. Plasma viscosity was slightly raised at $1.75 \mathrm{cp}$. Urine microscopy and culture were normal. Thyroxine was less than $30 \mathrm{nmol} / \mathrm{l}$ (normal range 70 to $140 \mathrm{nmol} / \mathrm{l}$ ) and the thyroid stimulating hormone concentration was greater than $60 \mathrm{mIU} / \mathrm{l}$ (normal range less than 6 $\mathrm{mIU} / \mathrm{l})$. An autoantibody screen, including rheumatoid and antinuclear factors, was negative apart from the presence of thyroglobulin antibodies positive in a titre of 1:1280. Thyroid microsomal antibodies were not detected. Circulating immune complexes were identified by platelet aggregation. Complement levels were C4 $22 \mathrm{mg} / 100 \mathrm{ml}$ (normal range 16 to $39 \mathrm{mg} / 100 \mathrm{ml}$ ), C3 $80 \mathrm{mg} / 100 \mathrm{ml}$ (normal range 101 to $198 \mathrm{mg} / 100 \mathrm{ml}$ ), and $\mathrm{C} 115 \mathrm{mg} / 100 \mathrm{ml}$ (normal range 12 to $30 \mathrm{mg} / 100 \mathrm{ml}$ ). Immunoglobulin values were $I g A 75 \mathrm{mg} / 100 \mathrm{ml}$ (normal range 50 to $130 \mathrm{mg} / 100 \mathrm{ml}$ ), IgG $1220 \mathrm{mg} / 100 \mathrm{ml}$ (normal range 650 to $1300 \mathrm{mg} / 100 \mathrm{ml}$ ), and IgM $125 \mathrm{mg} / 100 \mathrm{ml}$ (normal range 40 to $150 \mathrm{mg} / 100 \mathrm{ml}$ ). Lymphocyte subpopulation studies showed normal $T$ and $B$ cell profiles. There were no autoantibodies detected in her mother's serum. Radiographs of her knees and ankles were normal, and her bone age was compatible with her chronological age (TW2 $=3.6$ years).

She was started on L-thyroxine $(50 \mu \mathrm{g}$ orally daily) and at clinic review after two weeks the skin was less dry, the ankle joints less swollen, and she was walking normally. The thyroxine was increased to $75 \mu \mathrm{g}$ orally daily. At further review one month later she was clinically euthyroid and her bowel habit had returned to normal. The thyroxine concentration was $126 \mathrm{nmol} / \mathrm{l}$, and thyroid stimulating hormone was suppressed at $4 \mathrm{mIU} / \mathrm{l}$. Thyroglobulin antibodies and thyroid blocking antibodies were not now detectable, and the remainder of the autoantibody screen was still negative. Antibodies against a number of common viruses were estimated at this stage and were undetectable, apart from those to cytomegalovirus at a titre of $1: 32$. She continued to grow normally and remained clinically euthyroid on L-thyroxine ( $75 \mu \mathrm{g}$ orally daily) over a seven month period. Her thyroxine was then stopped for four weeks and her thyroid function reassessed. The serum thyroxine value decreased to less than 30 $\mathrm{nmol} / \mathrm{l}$ and the thyroid stimulating hormone value was again raised at greater than $60 \mathrm{mIU} / \mathrm{l}$, confirm- ing persisting primary hypothyroidism. Daily Lthyroxine treatment was reinstituted.

\section{Discussion}

Transient hypothyroidism in the neonate has been reported as an occasional accompaniment of exposure of the infant to circulating thyroid autoantibodies acquired from the mother, ${ }^{4}$ but the development of irreversible hypothyroidism in children is generally considered to represent either the decompensation of a congenitally small, ectopic, or dysplastic gland or the end stage of chronic destruction of the thyroid gland with associated autoimmune features. ${ }^{12}$ Permanent thyroid failure in the girl we have reported seems to be confirmed by the hypothyroid biochemistry obtained seven months after initial presentation, during the omission of her replacement treatment. The brief three week history of symptoms, however, and even more objectively, her normal growth, bone maturation, and development, support the idea that severe hypothyroidism developed rapidly. Growth has been recognised retrospectively as a sensitive marker of thyroid hormone status in children, a fall off in growth velocity often preceding symptomatic hypothyroidism by several years. ${ }^{1}$ The arthralgia, joint swelling, and skin bruising accompanied by low serum C3 values and circulating immune complexes favoured a generalised immunological disturbance at the time of onset of thyroid deficiency in our patient and the raised thyroglobulin antibodies implied associated thyroid damage. The disappearance, however, of these antibodies over a six month period would be in keeping with a short lived insult to the thyroid gland. The rapid resolution of the arthropathy on thyroxine treatment was also interesting. There were no clear pointers to the 'trigger' of the acute process and, in particular, there was no definite evidence of bacterial or viral infection. The latter, along with the absence of thyroid tenderness and the low concentrations of circulating thyroid hormones, makes a non-autoimmune, acute thyroiditis unlikely. Thyroid blocking antibodies were not detectable some months after the onset of hypothyroidism but this does not exclude their role in its causation.

Our observation of the seemingly acute onset of primary hypothyroidism in a 3 year old girl challenges the classic view that the development of thyroid failure in the context of thyroiditis is invariably a protracted process.

We thank Dr N R Steel, Endocrine Department, Newcastle Royal Infirmary for assaying thyroid blocking antibodies in the patient's serum and Caroline Parker for typing the manuscript. 
References

${ }^{1}$ Winter J, Eberlein WR, Bongiovanni AM. The relationship of juvenile hypothyroidism to chronic lymphocytic thyroiditis. J Pediatr 1966;69:709-18.

2 Woolner LB, McConahey WM, Beahrs OH. Struma lymphomatosa (Hashimoto's thyroiditis) and related thyroidal disorders. J Clin Endocrinal 1959;19:53-8.

${ }^{3}$ DeGroot LJ, Stanbury JB. The thyroid and its diseases; 4 th ed. London: John Wiley and Sons, 1975:415.
${ }^{4}$ Matisuura N, Yamada Y, Nohara Y, et al. Familial neonatal transient hypothyroidism due to maternal TSH-binding inhibitor immunoglobulins. N Engl J Med 1980;303:738-41.

Correspondence to Dr B P O'Malley, Department of Pharmacology, Leicester Royal Infirmary, Leicester LE2 7LX.

Received 3 May 1985

\title{
Reversible inhibition of central precocious puberty with a long acting GnRH analogue
}

\author{
P S WARD, I WARD, A W McNINCH, AND D C L SAVAGE \\ Bristol Royal Hospital for Sick Children and Southmead Hospital, Bristol
}

SUMMARY A 7 year old girl with precocious puberty was treated with buserelin, a long acting analogue of gonadotrophin releasing hormone. Spontaneous and stimulated gonadotrophin secretion became prepubertal but returned to pubertal values when buserelin was withdrawn, suggesting that normal sexual maturation should follow cessation of treatment.

Buserelin (6-D-Ser-(TBU)-GnRH-(1-9) ethylamide) returns pubertal gonadotrophin responses to intravenous gonadotrophin releasing hormone to prepubertal concentrations in children with precocious puberty. ${ }^{1}$ One reservation about this treatment, however, has been whether normal sexual maturation will follow its cessation. We report a child in whom pubertal gonadotrophin secretion returned after drug withdrawal.

\section{Patient and methods}

A girl aged 7.8 years presented in April 1983 with precocious puberty (Tanner stage P2B4). Ultrasound examination of the abdomen and computed tomography of brain were normal.

Gonadotrophin secretion was assessed during sleep and after intravenous gonadotrophin releasing hormone stimulation. Blood was withdrawn continuously by a Cormed SL-65 continuous blood withdrawal pump throughout the first few hours of sleep monitored by electroencephalogram.

Specimens were divided into aliquots collected over
15 minute periods. The following morning an intravenous gonadotrophin releasing hormone test was performed. Serum gonadotrophin concentrations were measured by radioimmunoassay.

Buserelin $(400 \mu \mathrm{g})$ was administered three times daily by nasal insufflation. Gonadotrophin secretion was assessed three months later. Treatment was stopped after nine months and testing was repeated after a further three weeks.

\section{Results}

The biochemical results are shown in the Figure. Pubertal gonadotrophin responses to intravenous gonadotrophin releasing hormone were abolished by buserelin and returned when the drug was withdrawn. During treatment, pulsatile gonadotrophin secretion was diminished. Withdrawal of buserelin was followed by pulsatile secretion of luteinising hormone and, to a lesser extent, follicle stimulating hormone. During and after treatment, basal gonadotrophin concentrations were rised compared with the values beforehand. The lower limits of detection of the gonadotrophin assays were $0.6 \mathrm{IU} / \mathrm{l}$ for follicle stimulating hormone and $2.0 \mathrm{IU} / 1$ for luteinising hormone. Interbatch coefficients of variance for follicle stimulating hormone were $10.8 \%$ at $3.8 \mathrm{IU} / 1$ and $3.2 \%$ at $10.2 \mathrm{IU} / 1$ and for luteinising hormone were $11.3 \%$ at $2.9 \mathrm{IU} / 1$ and $5.1 \%$ at $9.9 \mathrm{IU} / \mathrm{l}$. Serum oestradiol concentrations were 150,29 and $69 \mathrm{pmol} / \mathrm{l}$ before, during, and after treatment respectively. During nine months' treatment there was no clinical progression of puberty. 